\title{
Contrastive Pragmatics: Apologies \& Thanks in English and Italian
}

\author{
Cüneyt Demir ${ }^{1} \&$ Mehmet Takkaç ${ }^{2}$ \\ ${ }^{1}$ School of Foreign Languages, Siirt University, Siirt, Turkey \\ ${ }^{2}$ Faculty of Education, Atatürk University, Erzurum, Turkey \\ Correspondence: Cüneyt Demir, School of Foreign Languages, Siirt University, Siirt, Turkey. E-mail: \\ ardgelen@hotmail.com
}

$\begin{array}{ll}\text { Received: November 26, } 2015 & \text { Accepted: January 6, } 2016 \quad \text { Online Published: January 31, } 2016 \\ \text { doi:10.5539/ijel.v6n1p73 } & \text { URL: http://dx.doi.org/10.5539/ijel.v6n1p73 }\end{array}$

\begin{abstract}
Awareness of language or language competency has greatly changed from the focus of language itself as form and structure to language use as pragmatics. Accordingly, it is widely accepted that different cultures structure discourse in different ways. Moreover, studies have shown that this holds for discourse genres traditionally considered as highly standardized in their rituals and formulas. Taking inspiration from such studies, this paper employs a corpus-based approach to examine variations of the apology and thanking strategies used in English and Italian. First the apology itself as a form of social action is closely analyzed and then thanking. This study also pays special attention on analyzing and contrasting apology and thanking strategies in American English and in Italian in terms of Marion Owen's remedial strategies (Owen, 1983), and Olshtain \& Cohen's semantic formulas in the apology speech act set (Olshtain \& Cohen, 1983). The purpose of the study is not only to compare apology and thanking speech acts but to also learn their contextual use. The findings suggest that the status and role of the situation affect the speakers' choice of apology and thanking strategies, and semantic formulas are of great importance.
\end{abstract}

Keywords: apology, thank, English, Italian, gratitude

\section{Introduction}

Awareness of language or language competency has greatly changed from the focus of language itself as form and structure to language use as pragmatics. What was crucial in the past was crucial again; however the tendency of language had converted its face from heavy contented grammar books to the streets, where the language is for communication. A striking milestone in the history of language teaching, particularly what has come to be known as communicative language teaching, was Hymes' (1974) notion of communicative competence, which in language teaching moved the focus of syllabus design away from the grammatical syllabus to attempts to describe the nature of a communicative syllabus (Munby, 1978). The notion of communicative competence however, is based primarily on abilities of the native speaker while grammar competence - once upon a time was the primary aim of the linguistics'-is something reading comprehension.

It is explicit that even the most basic items in a language syllabus such as the use of, for example, hi, thanks or good evening can possibly bring about cross cultural misunderstanding owing to pragmatic differences between the languages. Loan translation is very commonly used in language teaching, which is, for me, a setback in front of conveying the meaning. The setback comes on your way when teaching even the simplest chunks. It is not so easy to say that the correspondence of "good evening" in English is "bouna sera" in Italian. Here things can be more problematic. Good evening is a frequent verbal strategy in English used in the sunset (not in the very late of the night) whereas to use its closest equivalence "bouna sera" in a conversation in Italian is likely to make the hearer a bit perplexed because it is not only used in the sunset but up to midnight. These errors of pragmalinguistic (Note 1) transfer can disrupt the smooth flow of talk or the intentions of the interlocutors (Thomas, 1983). According to Intachakra (2004, p. 38) more consequential of pragmalinguistics errors are errors of sociopragmatic (Note 2) transfer. For example, while an adult Italian may address to a younger "tu" (Note 3), it will be impolite, even rude, to be addressed as "tu" by a younger if you are an adult. So, an Italian language learner needs to be aware of the fact that $\mathrm{s} /$ he should never address an Italian who is superior in seniority or power by second-person singular but second person plural. 
As known, contrastive analysis was an important strand in applied linguistics a few decades ago, used extensively in the field of Second Language Acquisition (SLA) in the 1960s and early 1970s, as a method of explaining why some features of a Target Language were more difficult to acquire than others (Wikipedia, 2012). In more recent years, however, a resurgence of interest in cross-linguistic differences and their role in second language acquisition has existed, as is seen in the fields of contrastive rhetoric and cross- cultural communication studies. And with the growing interest in the notion of English as an International Language it is high time to reconsider the status of cross-linguistic differences, though broadening the scope of such studies to include comparing the pragmatic systems of languages in cross-cultural contact. This is the field of contrastive pragmatics. In the rest of this paper two speech acts will be compared in English and Italian; apologies and thanks through samples from different corpora.

\subsection{Vitality of the Context that Speech Act occurs}

The fact that the issue that the present study deals with is intricately related to pragmatics makes it compulsory to mention about contexts. Contexts are important aspects of interpreting utterances. In order to figure out the implicit meaning from what the speaker says, we need various types of information to understand the context of an utterance (Turan, 2011). According to Turan (2011), four kinds of contexts are crucial in getting the intended meaning of the conversations; Physical context, Epistemic context, Linguistic context, and Social context. Therefore, contexts where the interlocutors may share different norms for speech events, speech acts, and within-group communication needed to negotiate communication across cultures. Any context where English is used as a foreign language or as an international language can be viewed as a form of cross-cultural encounter and an occasion for possible differences in the norms governing conversational interaction to emerge. Intercultural competence can be defined as knowledge of culturally appropriate ways of communicating in a cross-cultural context using a second or foreign language (Intachakra, 2004). All mentioned in here sets forth the vitality of the context knowledge that the speech act has occurred.

\subsection{Speech Acts and Conversational Routines}

Speech act theory and conversational routines are two things at the hub of contrastive pragmatics. Without them, particularly the awareness of speech act, making sense from a conversation would be almost impossible, especially if you drop in conversation in the middle. The basic premise of speech act theory is that language is a means by which we not only convey information but also perform things for our own benefit (Austin, 1962; Searle, 1969). According to Searle (1969), early classifications of speech acts identified five major categories of speech acts: "representatives" (Note 4), "directives" (Note 5), "commissives" (Note 6), "expressives" (Note 7) and "declarations" (Note 8). Here it will not be fair not to emphasize Austin. According to him, speech acts can be analysed on three levels: locutionary act (it is the physical uttering of a statement), illocutionary force (it refers to the meaning or function the speaker assigns to such an act such as an attempt to persuade or reprimand) and perlocutionary effect (it is the impact of the first speaker's utterance on the next speaker. The speaker may intend to praise but the hearer may not necessarily recognize the utterance as such).

Our second important issue is "conversational routines". They are "highly conventionalized expressions whose occurrence is tied to more or less standardized communication situations" (Coulmas, 1981, pp. 1-3). For example, I'm sorry I do apologize. Whoops! Sorry about that. Oh, pardon me, and so on. Richards \& Sukwiwat (1983) argue that they are central to a learner's conversational competence since "they recur, are predictable, and are associated with particular social situations and with particular types of interactions". Speakers select appropriate routines from an extensive repertoire of stored utterances and their appropriate use not only gives a sense of authenticity or nativeness to their speech but also facilitates fluent talk (Pawley \& Syder, 1983). Therefore, failure to recognize the nature and function of the Target Language (TL) can cause negative transfer and result in miscommunication.

\section{Background Information about Apology and Thank}

\subsection{Conceptions of Apologies}

Many researchers and theorists regard apologies as speech acts that follow a perceived breach or transgression. The transgressor, recognizing both the transgression itself and his or her role in its occurrence, explicitly expresses regrets (Ely \& Gleason, 2006). Thus, the minimum constituents of an apology include a breach or transgression, the recognition of the transgression, the acceptance of responsibility for its occurrence by the transgressor, and a linguistic expression of remorse (Oh, I'm so sorry).

As dictionary definition, "apology" can be defined as "regretful acknowledgement of fault or failure; assurance that no offence was intended" (The Concise Oxford Dictionary of current English, 1980). From the definition we 
understand that they are not things that will not be forgiven. Apologies have also been viewed as pragmatic behaviour designed to preserve face especially when encountering face-threatening acts (Brown \& Levinson, 1987). From another point, according to Holmes (1989, p. 195), they are "face-supportive" acts. Research on speech acts has shown that apologies are among the more frequently used speech acts in people's daily affairs (Blum-Kulka, House, \& Kasper, 1989). In situations when the apology expectation was not fulfilled by the interlocutor or the mismanagement of apologies, there could turn out grave interpersonal consequences.

On the other hand apologies may be required to soften the tense settings or an offence. Olshtain (1989) gives an instance of a virtual collapse of the Israeli cabinet, which was eventually resolved after a painstaking negotiation forced the then Industry Minister to offer a suitable apology to the country's Premier. Another example of apology can be given as an incident involved a US surveillance aircraft making an emergency landing in China following a collision with a Chinese fighter jet. After extensive procrastination, the Chinese government put an end to the detention of the American air crew once it had received an official letter of apology from the US President (McGeary, 2001). A more recent example, which is still valid, can be shown as the high tension between Turkey and Israel after Israel Military Forces raided an international human-aid ship "named Mavi Marmara" and killed 9 activists. The Republic of Turkey asks for a formal apology from Israeli government while Israeli government does not lean to it. Why an apology -which is belong to the class of expressive- is seen so hard whereas we know that it has the ability of lowering the tense settings. Apologies are aimed at fulfilling communicative functions such as displaying regret and maintaining the negative face wants of interactants. Hence, the responsible party is required to redress the offended party's damaged personal autonomy by uttering an apology. Sometimes it is also possible that the offender may deny the responsibility, not perceiving himself/herself responsible for the act (Goffman, 1971). Factors such as the offender's own perception of the degree of severity of the offence, the recipient's point of view, age, familiarity and social status are major indicators in denying an apology, even when an apology is overwhelmingly needed.

There is not only one way kind of apology. Different situations or the degree of offending determines which apology strategy will be used. More, the choice of apology strategy depends on the nature of offence, the severity of the offence, the situation of the interaction, the familiarity of the individuals involved and the sex of the individuals (Fraser, 1981).

\subsection{Conceptions of Thanks}

People have both the negative face and positive face. The negative face is the need to be independent and free of any form of imposition, while the positive face is the person's need to be well treated, to belong, to be a member of a group (Yule, 2000). So, as Yule described, thanking act can be thought as a positive face. Thanking acts have in common with apologies in that they, too, satisfy the face wants of interactant. A face-saving act that emphasizes a person's positive face will show solidarity and be mindful of a common goal, tendency or a common weakness (Turan, 2011, p. 124). So, thanking act obeys politeness principle as a kind of face-saving act.

When compared, thanking acts have not attracted as much research as apologies (but see Eisenstein \& Bodman, 1986, 1993; Aijmer, 1996). However; apologies and thanking acts are not two acts totally at the different sides; as negative politeness strategies, apologies and thanking acts have a vital role in discourses such as restoring equilibrium among interlocutors and negotiating the offender or indebted. But, a crucial difference between is that whereas apologies are intended to rectify offences, thanking acts are aimed to compensate for debts. Therefore, as can be inferred so far, any failure to express apology or thank may elicit varying degrees of social sanction from those who are in the expectation of apology or thank.

\subsection{Aim}

Apologies and gratitude statements are two kinds of extremely frequent and routine speech acts (Ide, 1998). That is why these speech acts are going to be the issue of the study. On the other hand, having a throughout check-up in the literature, one is going to end up with the scare resources on contrastive studies conducted in bilingual; English (American) and Italian. Although there are umpteen studies done separately on English and Italian, it is hard to encounter any study that sets fort semantic similarities or differences of both languages in the same study. The present study emanated from that gap. That is the reason of why English and Italian languages were chosen as the core of the study.

Although apology and thanking speech acts are important parts of daily or formal conversations, as have been indicated before, thanking acts have not attracted as much research as apologies. The present study is divorced from the other studies in the literature in that it describes both apology and thanking acts as well as puts forward the contextual uses in English and Italian. Also the study investigates the apology and thanking strategies used 
by speakers in different apology and thanking situations. To articulate cultural differences in uses of "apology" and "thank" we focus on a comparison of just two cultures i.e. the study analyzes and contrasts apology and thanking strategies in English and in Italian in terms of formality, frequency, and contextuality. More, the study investigates the most frequently used apology and thanking strategies based on corpora, and then their formality from the most formal to the least; which one is used in which situations -contextual use. So at the end, it is hoped that the study is going to compile a comparable corpora for the stated speech acts, which currently there exist no parallel (Note 9) or comparable (Note 10) corpora of English \& Italian languages in the literature.

\subsection{Research Questions}

Given the paucity of data on English and Italian languages, it is set out to answer a number of questions about the use of and exposure to apology and thank terms. You will find 3 research questions in the following that guide the study:

(1) How are thanking and remedial strategies used in English and Italian?

(2) Are there different ways of expressing your amends and gratitude?

(3) Do Italian and English speakers' choice of thanking and apology speech acts and semantic formulas differ in terms of formality and contextual use?

\section{Analysis and Method}

In the analysis of the remedial interchanges the study focused on the frequency of use of Marion Owens' remedial strategies (see Appendix A) and of Olshtain \& Cohen's semantic formulas (see Appendix B) in the apology speech act set. Owen outlines remedial strategies that can be realized by both the offender and victim of the offense in order to bring about a restoration of interactional balance and she sets out strategies an offender can realize if he/she decides to undertake remedial work-Priming Remedial Move strategies (PRM). The study will not provide any remedial response or thank reciprocate strategies for apology and thank; that is the study focuses on apology and thanking strategies but not responses to the speech acts of apology and thank. Furthermore, the study is a descriptive study so there are no participants in the study. Samples from the corpora will be employed as subjects.

We know that the most common apology sub-formula in English, maintain Olshtain \& Cohen, is APOL, which is a subformula; an expression of regret: "I'm sorry". This sub-formula would fall under Owen's PRM strategy 3, showing attitude toward offense. This study compares the presence of these strategies and semantic formulas in the original sample texts to the strategies and semantic formulas used in Italian.

\subsection{Data}

The study is based on Data Driven Learning (DDL) so it is nourished from English and Italian Corpora. In the study, the examples -according to contextual situations- are extracted from the corpora and tried to create a comparable corpora for apology and thanking strategies in English and Italian. For English, COCA (Note 11) (Corpus of Contemporary American English) was the source for the study; whereas for Italian it was CLIPS (Note 12) (Corpora e Lessici dell' Italiano Parlato e Scritto), PAISÀ (Note 13) (Piattaforma per l'Apprendimento dell'Italiano Su corpora Annotati), and BADIP (Note 14) (BAnca Dati dello Italiano Parlato).

\section{Results}

There are different kinds of apology strategies as shown in the Table 1. The samples from the corpora exemplify the each strategy and sub-formulas one by one.

Table 1. Distribution of apology strategies

A. An expression of apology
Sub-formula A1. An expression of regret
Sub-formula A2.An offer of apology
Sub-formula A3.A request for forgiveness
B. An account or explanation of the act
C. An acknowledgement of responsibility
Sub-formula C1. Accepting the blame
Sub-formula C2. Expressing self-deficiency
Sub-formula C3. Recognizing the other person deserving apology
Sub-formula C4. Expressing lack of intent
D. An offer of repair
E. A promise of forbearance




\subsection{Apologies in English}

\section{A. An expression of apology}

The strategy A is related to making an explicit display of apology, and can be further broken down into three individual sub-formulas (see Table 1).

\section{Sub-formula A1. An expression of regret}

(1) I could've not been on speed. I should not have been on speed and maybe this wouldn't have happened.

\section{Sub-formula A2. An offer of apology}

(2) We have fixed the microphone problem. I apologize for that, but I'm glad that you're with us.

Sub-formula A3. A request for forgiveness

(3) Let me just inter-let me just interrupt you, and I-I beg your pardon for doing so.

\section{B. An account or explanation of the act}

The strategy B "An account or explanation of the act" involves giving either an explanation or account of why the transgression was inevitable. For example, we can say that a question takes so long time to answer especially if it is an easy one; here, lateness is seen as an object of offence. Also, it necessitates using the strategy B when your favourite vase was accidentally broken. That strategy is of quite frequent occurrence in our collected data.

(4) I regretted what I had said. I had not meant it to be an accusation, but she took it that way.

(5) I have a lot of guilt, though, because I feel like it was my fault because I didn't stop it, because it was just a lot easier to take then.

(6) I definitely plead guilty, because I know I didn't do nutrition right in my home. And, you know, I'm - I'm paying for it now.

\section{An acknowledgement of responsibility}

The strategy $\mathrm{C}$ constitutes an acceptance of responsibility on the part of the offender and has a further set of three sub-formulas, as in the following:

\section{Sub-formula C1. Accepting the blame}

This self-reproaching device acts as a token that the offender acknowledges that the fraction he/she has evoked is a result of his/her own doing, not that of the offended interlocutor. The example in the corpus is, the relatively formulaic expression such as: it's my fault.

(7) I overheard my brother and sister saying it was my fault she left because I was a brat. And I'm sure I was.

\section{Sub-formula C2. Expressing self-deficiency}

At first look, this sub-formula looks like a close repetition of the strategy B and sub-formula C1, however; here the speaker spells out his/her own self-deficiency.

(8) I'm sorry, I have to apologize, I didn't know anything about any accident.

Sub-formula C3. Recognizing the other person deserving apology

The speaker specifies that he/she perceives that the offender is entitled to an offer of apology, by saying you are right or you deserve an apology (Holmes, 1990, p. 167).

(9) I think you should apologize for it, and I think you should recognize that having differences of opinions on issues does not justify labelling people with highly charged epithets.

Sub-formula C4. Expressing lack of intent

In sub-formula $\mathrm{C} 4$, "Expressing lack of intent" the offender explicitly expresses that the wrongdoing was, indeed, not intended to be a malicious act.

(10) I did not mean to offend you. I understand your resentment, but tell me, in your opinion, how should I have reacted to the questions of that woman?

\section{An offer of repair}

The strategy D "An offer of repair" wishes to re-establish the spoiled camaraderie by offering either a verbal or material compensation to the addressee. Some illustrations are:

(11) He nodded. Ain't no food left for Mr. Self in the kitchen, though. Sorry. But there is a restaurant nearby. 
(12) Oh, I forgot to bring them. But they're pretty much the same ones you've got.

\section{E. A promise of forbearance}

As last in the strategy E "A promise of forbearance", the speaker presents the hearer with assuring words that a compensative action would be taken or that the same mistake would not be reiterated.

(13) Today, commandos rappelled down buildings and police showed off new gear in an attempt to reassure Mumbai residents, it will not happen again.

(14) That's what we wound up with, and an economy that was in the ditch. So the -- the point here is we don't want to repeat the same mistake.

\subsection{Apologies in Italian}

\section{A. An expression of apology}

Sub-formula A1. An expression of regret

(15) Mi vergogno per quello che ho fatto

(I am ashamed of what I have done)

(16) Mi sento molto in colpa per cio' che ho fatto

(I feel very guilty for the thing I have done)

Sub-formula A2. An offer of apology

(17) Paul Newman comprò una pagina di un quotidiano Nazionale per chiedere scusa per la sua interpretazione.

(Paul Newman allocated a full page in an national newspaper to apologize for his performance in the race)

Sub-formula A3. A request for forgiveness

(18) Mi dispiace immensamente, non so come farmi perdonare.

(I deeply regret, I don't know what could I do to be forgiven)

\section{B. An account or explanation of the act}

(19) Non volevo pestarti il piede. Perdonami per favore.

(I hadn't meant to step on your feet. Forgive me please)

\section{An acknowledgement of responsibility}

\section{Sub-formula C1. Accepting the blame}

(20) Scusa del ritardo, Adriana, è tutta colpa mia , spero che mi perdonerai.

(Sorry for the delay, Adriana, it's all my fault, I hope you will forgive me)

Sub-formula C2. Expressing self-deficiency

(21) Non ho notato il vaso sul tavolo. In caso contrario, non avrebbe rotto.

(I did not notice the vase on the table. Otherwise, I would not have broken it)

Sub-formula C3. Recognizing the other person deserving apology

(22) Penso che è necessario chiedere scusa perché vi era colpa.

(I think you should apologize because it was your fault)

\section{Sub-formula C4. Expressing lack of intent}

(23) Non era mia intenzione stabilire la verità su un caso già ampiamente discusso, ma mostrar- vi la posizione di chi è rimasto indignato da un certo modo di rappresentare Tenco.

(I hadn't meant to challenge the truth of the decision already discussed by you, but only to show that there is the position of those who remained outraged from a certain way to represent Tenco)

\section{An offer of repair}

(24) Ho perso il tuo libro, ma c'è ancora una alla vendita in libreria.

(I have lost your book but there is still one left at sale in bookshop)

\section{E. A promise of forbearance}

(25) Non l'ho fatto intenzionalmente. E' stato un incidente, non succederà mai più. 
(I have not done it intentionally. It was an accident, it will never happen again)

\subsection{Thanks in English}

There are more 300 thanking exchanges in English corpus amount to a total of 405 separate gratitude moves (Intachakra, 2004). They were classified based on Eisenstein \& Bodman (1986) and Aijmer (1996). Thanking strategies are seen in the following Table 2.

Table 2. Distribution of thanking strategies
A. An explicit expression of gratitude
Sub-formula A1. Use of performative
Sub-formula A2.Offer of gratitude
Sub-formula A3. Expressing indebtedness
B. An account or acknowledgement of favour
C. An expression of admiration
Sub-formula C1. Admiration of the act
Sub-formula C2. Admiration of the addressee
D. An indication of unnecessity of favour
E. A promise of repayment

\section{A. An explicit expression of gratitude}

\section{Sub-formula A1. Use of performative}

This sub-formula is related to offering explicit thanks in formal speech events and necessitates a first-person subject and a speech act verb such as thank or appreciate.

(26) I would like to thank all the police officers. For what they've done to save my daughter; I thank you on behalf of Paul and I appreciate that.

\section{Sub-formula A2.Offer of gratitude}

In that sub-formula, the most common elliptical expressions such as thank you, thanks, and thanks for doing something emerge as offer of gratitude. Although two thanking acts -cheers and ta-very found in British English, they are not much used in American English. A typical example for that kind of thanking formula undoubtedly comes from a TV channel (CBC morning) as frequently bumped into.

(27) Well, good morning everybody and thanks for joining us. I'm Betty Nguyen. This morning it looks like the Florida primary is a race that is going down to the wire.

\section{Sub-formula A3.Expressing indebtedness}

"Expressing indebtedness" formula are by and large done through chunks or fixed expressions such as $I$ am much obliged, I am grateful, I am thankful etc. The syntactical structure is generally in the order of " $I+$ copula + adjective" as seen in the chunks and fixed expressions above. The corpora texts show that this formula is used when something is requested or to the addressee for already done a favour for you.

(28) I'd be much obliged if I could just have a piece of that chicken or maybe some of that bread.

\section{B. An account or acknowledgement of favour}

The strategy B is divorced from the other strategy types in that it covers illocutionary intent rather than grammatical indicators. An "account" or an "acknowledgement of favour" does not push on to convey gratefulness, but only suggests the positive effect that the favour has on the speaker instead.

(29) So it's goodbye and please come again. Gerry Burke and his friends most likely will return, but their hopes and fears will travel with them.

Here in the example 29, we see that the journalist acknowledges the devotion of the guest for participating to his/her program by saying "please come again".

\section{An expression of admiration}

The strategy $\mathrm{C}$ encompasses compliments and other verbal elements that head toward the speaker's optimism concerning the hearer's prospective undertakings. This strategy can be divided into two further moves to determine whether the addresser chooses to concentrate on the beneficial act itself or the addressee (Aijmer, 1996, p. 38). 


\section{Sub-formula C1. Admiration of the act}

This sub-formula thanking act contains specific reference to the act worthy of appreciation. It is broadly used to strengthen the correlation between the parties. An individual may submit gratitude to another person for his/her benevolent deed. It is generally used with an extra expression sentence such as it was really nice to be with you (a journalist to the guest after an interview) or it was your kind (having thanked for helping you carry the suitcase in an airport).

(30) Thank you. It was nice to be with you, Ray. (from PBC News hour: anchorman to his/her guest)

\section{Sub-formula C2. Admiration of the addressee}

Here, the speaker focuses on the hearer and states his/her admiration with the statements such as best wishes, good luck or you deserve it etc. after thanking.

(31) Beginning with the current mini-series and continuing with Susan Sheridan's editorship, I know that School Psychology Review has a bright future and will pave the way for our profession's continued success. Best wishes to Susan and all persons associated with the journal!

\section{An indication of unnecessity of favour}

The strategy D expresses the gratitude of the speaker by means of a discouraging statement. Some examples from the corpus are: you shouldn't have; I didn't expect you to do that; and you didn't have to do it. By using any such phrases, the speaker is not in the mind of turning down an offer or assistance but the vice versa. Culturally we know that that kind of strategy is not widely used in American daily conversations. Therefore, it is hard to run into samples of these kinds of discouraging statements in the corpora data. One exclusive example follows:

(32) There's no need to thank me. "His voice came out gruffer than he intended, a low rumble in the dark."

(33) Aunt Ethel squeezed Emily's forearm. No need to thank us, dear. It's our pleasure to help.

(34) Come on. There's no - there's no need to applaud. It's nothing great. You guys, I accepted an invitation, and I'm staying true to my word.

\section{E. A promise of repayment}

The strategy E commits the thanking act and states a future favour for repayment to the addressee. Here, there is a high feel of indebtedness and gratitude for the done by the hearer.

(35) S: Well, may I say, Arnold, no one wishes you more than I do. You're a great guy and a great friend for years. We look forward to seeing it. A big weekend. Wish you everything you wish yourself.

$H$ : Thank you, Larry. Thank you. And next time I'm going to bring you some new suspenders. This is out. Navy blue is out.

\subsection{Thanks in Italian}

Italian has a wonderful array of ways to say thank you: grazie (thanks), grazie infinite (endless thanks), grazie mille (thanks a thousand, literally, but it is translated as thanks a million), molte grazie (thank you very much), and grazie di cuore (thanks from the heart). While "thanks or thank you" can be used both as in formal and informal contexts, the contextual formality is crucial in Italian. Even, sometimes it can be insincere if you use formal thanking way to one of your close friend. Formality ranking is show in Figure 1. Then, in the following examples we see the strategy use of Italian speakers.

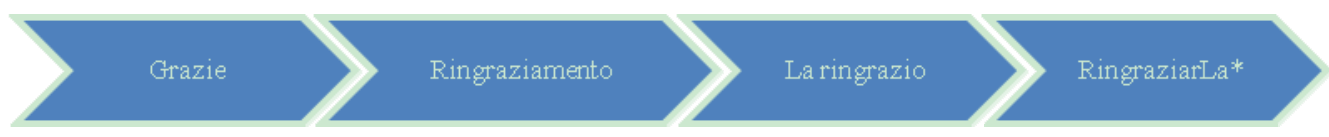

Figure 1. Formality ranking of thanking lexeis (towars to more formal)

Note. * Although the only change between "La ringrazio" and "RingraziarLa" sounds like a pronoun change, there exists a minor contextual use diversity. 
There is a common accepted contextual use of thanking in Italian. That is; the lexis "grazie" can be used in both formal and informal situations while the most formal one "ringraziarLa" is only used in formal situations. It will be unacceptable to use a formal thanking way in a sincere context.

\section{A. An explicit expression of gratitude}

\section{Sub-formula A1. Use of performative}

As stated for the example 26, this sub-formula is related to offering explicit thanks in formal speech events and necessitates a first-person subject and a speech act verb. In the example below we can get the formality of the situation. Here the speaker chooses to use a formal thanking speech act. It would be certainly unsuitable for the formality of the context if said "Grazie".

(36) La ringrazio, comunque, per l' opportunità concessami nel porre per primo i quesiti ai nostri ospiti: non so molto più degli altri colleghi, ma ho vissuto queste vicende negli anni citati presso la Commissione agricoltura della Camera dei deputati...

(Thank you, however, for the first opportunity given to me in putting the questions to our guests: I do not know much more than the other fellows, but I experienced these events in the years mentioned in the Agriculture Committee of the Chamber of Deputies...)

\section{Sub-formula A2.Offer of gratitude}

That sub-formula is used for expressing the gratitude of the beneficiary. The use changes based on the situation of the formality. In the example below a casual setting sample was extracted.

(37) Buonasera a tutti amici ascoltatori grazie grazie ahah questa sera non vedremo piu' Pierangela Ballerini la campionessa di Genova che ha destato tanto interesse con la sua materia veramente fuori dell' usuale direi anche tanto scandalo be' se n' e' andata con settecentoventisette milioni in tasca.

(Good evening to all my listener friends. Thanks and thanks. This evening you will not see more "Pierangela Dancers" of champion Genova, which has aroused much interest with their unusual incident. Indeed I would say their scandal; pocketing seven hundred twenty seven million).

\section{Sub-formula A3.Expressing indebtedness}

This kind of sub-formula generally requires informal and sincere thanking act because there exists a sacrifice and generosity in the situation and this is only realized by a close familiar.

(38) Non trovo parole per dirLe quanto ci ha fatto piacere - Grazie mille, grazie tanto per la regalo.

(I cannot find the words to tell you how much pleasure it gave me. Thanks a thousand time, thank you very much for your gift).

\section{B. An account or acknowledgement of favour}

In the strategy B, we acknowledge a favour sometimes without thanking explicit. As seen in the example 39, the speaker is pleased with the musical talent of the children. There is also an implicature in the discourse. It is understood that in fact the parents are in the favour of supporting that talent because they are the listeners of a conference related to music talent. So the speaker seems a bit thankful and express that in the example below.

(39) ...Perciò genitori, se vostro figlio ha del talento per la musica, per favore permettetegli di sviluppar di piu!

(...therefore parents, if your child has a talent for music, please allow it to grow more!)

\section{An expression of admiration}

That strategy covers both formal and informal contexts. The first sub-formula $\mathrm{C} 1$ is an expressing way for an act done for generosity and sake of the beneficiary. $\mathrm{C} 1$ broadly includes a physical effort or a concrete action. On the other hand, the sub-formula $\mathrm{C} 2$ is different a bit from $\mathrm{C} 1$ in that the effort or the action is not done directly for the sake of the beneficiary as shown in examples 30 and 31 .

\section{Sub-formula C1. Admiration of the act}

(40) Petrucci ha inoltre aggiunto Al governo dico grazie per quello che ha fatto, ma chiediamo investimenti nelle strutture.

(Petrucci has also added The government say thanks for what he did, but we ask investments in facilities.)

Sub-formula C2. Admiration of the addressee

(41) Riposa in pace - grazie per la tua musica e per la tua figura. 
(Rest in peace - thanks for your music and for your figure)

\section{An indication of unnecessity of favour}

We see from the samples in the corpora that Italians use that kind of thanking strategy much more than the Americans do. The beneficiary expresses his/her gratitude to the addressee by means of a discouraging statement.

(42) Non hai bisogno di comprare un nuovo iPad per me.

(You need not have bought a new ipad for me)

\section{E. A promise of repayment}

Here, in the strategy E, we are aware that there is a repayment in exchange for a sacrifice or favour done by the performer beforehand. In the example 43, it is understood that the beneficiary promises to work harder from now on. That points that the beneficiary got a favour and has not covered what $\mathrm{s} /$ he should do until that time. Consequently, s/he promises, which can be seen as a thanking act for done.

(43) Ti prometto che mi impegnerò in una ricerca approfondita per scovare nuovi libri che possano soddisfare le tue ( e anche mie ) curiosità.

(I promise you that I will work harder to find new books that can satisfy your (and my) curiosity)

\section{Conclusion}

Guided by Robinson's (1994) approach to studying the complex interrelationships among language, cognitions, emotions, social perceptions, and judgments, the present study investigated the samples of apology and thank across cultures. Shortly, throughout the study we saw two speech acts and two societies in contrast.

Furthermore, this study of the speech acts of apologizing and giving thanks in English and Italian highlights a number of subtle differences between conversational interaction in the two speech communities. There are almost the same number of strategies for thanking in English and in Italian (see Appendix C), not only in terms of frequency but also of quantity.

The corpora for English put forward all the major thanking strategies. They are: thanks, I thank, many thanks, thank you, I appreciated, much obliged, I am grateful, cheers, ta etc. But from the sample numbers it is understood that the most frequent thanking way from the most frequent variants is thank you (see Appendix C).

On the other hand, a significant difference however, can be found in the availability of thanking strategy of D in English and Italian. Reactions toward thanking change in the strategy D. While Americans do not much understand and use that kind of thanking, Italians use it commonly (see examples 32, 33, 34 and 42). For Italian thanking, we see many ways of it. What is striking is that some of thanking style in Italian cannot be translated into English as loan-translation. For example, "grazie di cuore" is a formulaic expression in Italian and translated as "thanks from the heart". Although the use of it is very common in Italian, that kind of thanking act in English is too rare to mention; understood when the English corpora surveyed.

Let us put the answer of the research questions shortly: as regards RQ1, "How are thank and remedial strategies used in English and Italian?" It can be definitely said that the strategies and sub-formulas are used differently in diverse situations. The level of gratitude and regret determine the use of apology or thanking strategy that you will choose. Although examples (1) and (11) are both under the title of apology, they are totally different in semantic and cannot be interchanged; that is you cannot use the strategy which is used in example (11) for the situations in (1). The case is the same for amending situations. If we take the examples (15) and (19), we will notice that the level of the mistake determines your use of strategy or sub-formula. While the apology in (15) is a serious for, the case is not the same in (19). So the interlocutors decide which one to choose according to the semantic of the discourse or situation.

RQ2: "Are there different ways of expressing your amends and gratitude?" The study formed a data for you in the appndx 3 that put forwards the gratitude sorts. It is seen that the most thanking way is "thank you" in English while it is "grazie" in Italian. There are also different ways of expressing your amends in both languages. The corpora demonstrate that the most commons in English are (not in ranking!) "(1) I apologize for that, (2) I beg your pardon, (3) I regretted, (4) it was my fault, (5) I definitely plead guilty, (6) I'm sorry, I have to apologize, (10) I did not mean to offend you, and (11) Sorry" whereas (16) Mi sento molto in colpa, (17) scusa per la sua interpretazione, (18) Mi dispiace, and (19) Perdonami are the most widespread ones in Italian.

As regards our last research question, "Do Italian and English speakers' choice of thanking and apology speech acts, and semantic formulas differ in terms of formality and contextual use?" we get as seen in the result of the 
study that there are many ways of thanking and apologizing. The use changes according to the formality of the situations. Although apology strategies do not shift much concerning the formality of the situations, thanking strategies change. As far as we have got from the texts in the corpora, it will be certainly unacceptable to use "cheers or $t a$ " in English in formal contexts because no sample or data on such a kind of use were detected. The case is same for Italian language in terms of formality. The samples provide that the apology strategies are not all the same for all the contextual situations: formal or informal. In spite of existing of formal thanking strategies (see Figure 1), the one that can be thought as informal "grazie" is acceptable for formal situations while the one that is used for formal situations "ringraziarLa" is not acceptable for informal situations. Also, it will be useful to state that the corpora examples show that the formal thanking strategy is more common in formal situations although all acceptable.

\section{References}

Aijmer, K. (1996). Conversational Routines in English: Convention and Creativity. London: Longman.

Austin, J. (1962). How to Do Things with Words. Oxford: Clarendon Press.

Blum-Kulka, S., House, J., \& Kasper, G. (1989). Cross-Cultural Pragmatics: Requests and Apologies. Norwood: Ablex Publishing Corporation.

Brown, P., \& Levinson, S. C. (1987). Politeness: some universals in language usage. New York: Cambridge University Press.

Coulmas, F. (1981). Introduction. In Conversational Routine: Explorations in the Standardized Communication Situations and Prepatterned Speech (pp. 1-17). Mouton Publishers.

Eisenstein, M., \& Bodman, J. (1986). 'I very appreciate': An Expression of Gratitude by Native and Non-Native Speakers of American English. Applied Linguistics, 167-85. http://dx.doi.org/10.1093/applin/7.2.167

Eisenstein, M., \& Bodman, J. (1993). Expressing Gratitude in American English. In G. Kasper \& S. B. Kulka, Interlanguage Pragmatics (pp. 64-81). Oxford: Oxford University Press.

Ely, R., \& Gleason, J. (2006). I'm sorry I said that: apologies in young children's discourse. Journal of Child Language, 599-620. http://dx.doi.org/10.1017/S0305000906007446

Fraser, B. (1981). Conversational Routine. In F. Coulmas (Ed.), On apologizing (pp. 259-272). Hague: Mouton.

Goffman, E. (1971). Relations in public. Harmondsworth: Penguin.

Holmes, J. (1989). Sex differences and apologies: One aspect of communicative competence. Applied Linguistics, 194-213. http://dx.doi.org/10.1093/applin/10.2.194

Holmes, J. (1990). Apologies in New Zealand English. Language in Society, 55-99. http://dx.doi.org/10.1017/s0047404500014366

Hymes, D. (1974). Foundations in Sociolinguistics: An Ethnographic Approach. Philadelphia: University of Pennsylvania Press.

Ide, R. (1998). "Sorry for your kindness": Japanese interactional ritual in public discourse. Journal of Pragmatics, 509-529. http://dx.doi.org/10.1016/S0378-2166(98)80006-4

Intachakra, S. (2004). Contrastive Pragmatics and Language Teaching. RELC Journal, 37-62. http://dx.doi.org/10.1177/003368820403500105

McGeary, J. (2001). Safe Landing: Spy Plane Finale. Time, 38-41.

Munby, J. (1978). Communicative Syllabus Design. Cambridge: Cambridge University Press.

Olshtain, A., \& Cohen, E. (1983). Apology: a speech-act set. Wolfson and Judd, 18-35.

Olshtain, E. (1989). Cross-Cultural Pragmatics: Requests and Apologies. In J. House \& G. Kasper (Eds.), Apologies across Languages (pp. 155-173). Norwood: Ablex Publishing Corporation.

Owen, M. (1983). Apologies and remedial interchanges: A study of language use in social interaction. The Hague: Mouton.

Pawley, A., \& Syder, F. (1983). Two Puzzles for Linguistic Theory: Native-like Selection and Native-like Fluency. In J. Richards \& R. Schmidt (Eds.), Language and Communication (pp. 191-226). London: Longman.

Richards, J., \& Sukwiwat, M. (1983). Language Transfer and Conversational Competence. Applied Linguistics, 113-125. http://dx.doi.org/10.1093/applin/4.2.113 
Robinson, W. P. (1994). Reactions to falsifications in public and interpersonal contexts. Journal of Language and Social Psychology, 497-513. http://dx.doi.org/10.1177/0261927X94134007

Searle, J. (1969). Speech Acts: An Essay in the Philosophy of Language. Cambridge: Cambridge University Press. http://dx.doi.org/10.1017/CBO9781139173438

The Concise Oxford Dictionary of current English. (1980). London: Book Club Associates: Oxford press.

Thomas, J. (1983). Cross-cultural Pragmatic Failure. Applied Linguistics, 91-112. http://dx.doi.org/10.1093/applin/4.2.91

Turan, U. (2011). Pragmatics. TURKISH SYNTAX, SEMANTICS, PRAGMATICS AND DISCOURSE (pp. 109-110). Eskişehir: Anadolu University Press.

Yule, G. (2000). Pragmatics. Oxford: Oxford University Press.

\section{Notes}

Note 1. An incongruence of translatability from one language to another.

Note 2. A mismatch of culture-specific assumptions about topics, size of impositions, rights and obligations of the interactants, etc.

Note 3. Unlike English, Italian has 2 forms of addressing to the person ahead: second person singular and second person plural. The first is "tu", which means "you" and used only if the person is very close and near aged. The latter form is "voi", which again means "you" but used if the person is older than you or the speaking context is formal.

Note 4. a perceived truth condition of an utterance

Note 5 . a request to perform an action

Note 6 . a commitment to carry out a future undertaking

Note 7. a manifestation of attitudinal dispositions

Note 8. an announcement that alters a state of affairs

Note 9. The term parallel corpora is typically used in linguistic circles to refer to texts that are translations of each other.

Note 10. The term comparable corpora refers to texts in two languages that are similar in content, but are not translations.

Note 11. http://corpus.byu.edu/coca/

Note 12. http://www.clips.unina.it/it/corpus.jsp

Note 13. http://www.corpusitaliano.it/

Note 14. http://badip.uni-graz.at/

\section{Appendix A}

\section{Owen's Priming Remedial Move}

Priming Remedial Move Strategies:

Strategy 1: asserting imbalance showing deference. This is sometimes communicated through gestures, tone of voice, rarely through verbal expressions.

"I am unable to look you in the eye".

Strategy 2: asserting an offense has occurred.

"I have caused you trouble."

Strategy 3: expressing, attitude towards offense, "expressing regret for disturbance caused to victim".

"I'm really sorry".

Strategy 4: requesting restoration, of balance, an explicit request to the victim. Owen, offers "Excuse me" as an example in English. 


\section{Appendix B}

\section{Olshtain and Cohen's Semantic Formulas and Sub-Formulas}

1. An expression of apology

sub-formula a: an expression of regret. "I'm sorry".

sub-formula b: an offer of apology'. "I apologize".

sub-formula c: a request for forgiveness. "Excuse me".

2. An account or explanation of the act.

3. An acknowledgement of responsibility.

sub-formula a: accepting the blame. "It's my fault"

sub-formula b: expressing self-deficiency. "I was confused".

sub-formula c: recognizing the other person deserving apology. "You're right".

sub-formula d: expressing lack of intent. "I didn't mean to."

4. An offer of repair.

This could be in the form of an offer to pay for any damages incurred.

5. A promise of forbearance.

"It won't happen again".

\section{Appendix C}

\section{Thanking Speech Acts and Frequencies in English and in Italian}

English

\begin{tabular}{ll}
\hline Thanking way & Frequency \\
\hline Thank you (very much) & 86470 \\
Thanks & 58191 \\
Ta & $8759^{*}$ \\
I appreciate it indeed! & 3056 \\
Cheers. & $2946^{*}$ \\
Many thanks! & 255 \\
Much obliged & 69 \\
I am so grateful. & 49 \\
Thanks a bunch. & 33 \\
Thanks a million! & 25 \\
I can't say enough thanks to you & 1 \\
\hline
\end{tabular}

Note. $*$ There are different semantic uses. The only use is not for thanking. They bear some other meanings so the frequencies are high.

Italian

\section{Copyrights}

\begin{tabular}{ll}
\hline Thanking way & Frequency \\
\hline Grazie | Thank you & 333 \\
Ringraziamento| Sincerest thanks & 178 \\
Grazie mille | Thank you very much (literally: A thousand thanks) & 60 \\
Grazie di cuore | Thanks from heart & 32 \\
Grazie di tutto | Thanks for everything & 24 \\
Grazie tante | Thank you so much, Thanks so much & 15 \\
Molte grazie | Many thanks & 7 \\
Mille grazie | Thank you very much & 6 \\
Grazie infinite | Thank you so much & 3 \\
RingraziarLa | Sincerest thanks & 1 \\
\hline
\end{tabular}

Copyright for this article is retained by the author(s), with first publication rights granted to the journal.

This is an open-access article distributed under the terms and conditions of the Creative Commons Attribution license (http://creativecommons.org/licenses/by/3.0/). 